\title{
PROFESSIONAL DEVELOPMENT FOR GEOGRAPHICALLY DISPERSED FACULTY
}

\author{
EMERGING TRENDS, ORGANIZATIONAL \\ CHALLENGES, AND CONSIDERATIONS FOR \\ THE FUTURE
}

\author{
Emily Donnelli-Sallee, Amber Dailey-Hebert \\ Park University \\ B. Jean Mandernach \\ Grand Canyon University
}

The growth of distance education programs has significantly influenced learner demographics and dispositions; bowever, often overlooked is its concomitant effect on the characteristics and needs of faculty. As institutions continue to diversify their educational offerings and faculty appointments, innovative, inclusive professional development models are vital for faculty success. A qualitative study of thirty institutions identified trends in faculty development programming, including an emphasis on collaborative course and program development, virtual learning communities and mentoring, and professionalism of contingent faculty roles. Findings

This research was generously supported by a grant from the Professional and Organizational Development Network in Higher Education. 
highlight the importance of decentralized, networked development models for geographically dispersed faculty.

It is seldom disputed that the growth of online and distance education has significantly influenced learner demographics and dispositions; however, often overlooked is its concomitant effect on the characteristics and needs of faculty. Consequently, faculty developers are challenged to support audiences beyond the full-time and adjunct faculty who teach courses on their institutions' primary physical campuses. Institutions now include a diverse faculty body comprising many full-time and adjunct faculty who work remotely, are not required to serve physically at their institution's flagship campus, have instructional release time for varied projects, and occupy diverse contractual agreements. As a result, faculty developers now work with faculty from geographically dispersed locations, including faculty teaching online or otherwise remotely at branch campus locations. These faculty possess varying levels of physical and psychological connection to their institutions, hold diverse appointments, and often face limited opportunities for professional development (Bower, 2001; Eaton, 2001; Gappa, Austin, \& Trice, 2007; National Center for Education Statistics, 2007). As institutions continue to diversify their educational offerings and faculty positions, innovative, inclusive professional enhancement models become even more vital.

To pursue a deeper understanding of effective professional development programming for this expanded faculty audience, researchers from two universities with large distance learning programs undertook a qualitative study of thirty institutions across the spectrum of Carnegie Basic Classifications (including private, public, and nonprofit institutions). The study yielded information about emergent trends in faculty development, primarily in the areas of collaborative course and program development, virtual learning communities, and professionalization of contingent faculty roles, as well as examples of innovative programming across institutional type. However, most significant, and surprising given our focus on identifying strategies and best practices, were interviews that overwhelmingly focused on the impact of organizational factors on faculty development and the pragmatic and epistemological considerations surrounding various models for supporting geographically dispersed faculty.

Thus, in this chapter, we address ways that institutional dynamics constrain and propel the growth of faculty development initiatives and the benefits and costs associated with centralized, decentralized, and hybrid organizational models. This knowledge can aid faculty development 
stakeholders in determining how to best integrate diverse faculty development goals and programs across academic departments, teaching centers, and distance learning administrative offices. Our contention is that an analysis of institutional organizational dynamics is a requisite first step to developing and sustaining effective, inclusive development programs for geographically dispersed faculty.

\section{Geographically Dispersed Faculty: Context and Growth Factors}

The context and characteristics of higher education are changing dramatically as we experience a significant paradigm shift in the academy. Gappa et al. (2007) identified four major forces currently affecting higher education institutions and their faculty members: “1) fiscal constraints and increased competition, 2) calls for accountability, 3) growing enrollment and increasing diversity of students, and 4) the rise of the Information Age, with its continuous expansion of new technologies" (p. 15). Certainly online learning is a primary influence on Gappa et al.'s (2007) observations about the role of new technologies. Based on a survey of twenty-five hundred colleges and universities nationwide, the Sloan Consortium found that approximately 5.6 million students were enrolled in at least one online course in fall 2009, representing a growth of over 1 million online students from the previous year (Allen \& Seaman, 2010). The ever-increasing student interest in online education has mandated more involvement from adjunct and full-time faculty. According to the National Center for Education Statistics (2010), 49 percent of instructional staff in degreegranting postsecondary institutions hold part-time or contingent positions. A study by the Association of Public and Land-Grant Universities (Seaman, 2009), which included both full-time and adjunct faculty at sixty-nine public institutions across the country, indicated that more than one-third of public university faculty have taught an online course.

Further diversifying faculty roles and the locations for faculty work is the growth of other forms of distance education, specifically the trend toward branch or satellite campuses. In addition to domestic branch campuses, typified by institutions such as Penn State and the University of California system, international branch campuses are on the rise, up 43 percent in just three years according to a 2009 study by the Observatory on Borderless Higher Education (Jaschik, 2009). Unlike state or even nationwide branch campuses, international campuses particularly accentuate the phenomenon of geographically dispersed faculty: some of these faculty may never, or very rarely, set foot on their institution's flagship 
campus. As a result of these factors and the varied instructional modalities now available, the traditional faculty role and related professional development needs are being redefined for both full-time and adjunct faculty.

\section{Beyond Training to Development: The Challenges of Working with Geographically Dispersed Faculty}

Conversations about the needs of geographically dispersed faculty typically focus on training faculty, primarily adjunct faculty, to teach and develop courses online (Cranton, 2005). The Association of Public and Land-Grant Universities' report (Seaman, 2009), The Paradox of Faculty Voices: Views and Experiences with Online Learning, which assessed campus support structures for full-time and adjunct faculty teaching online, affirms this well-established emphasis on technology training. Faculty respondents ranked only one of eight faculty support dimensions as acceptable: technology infrastructure. Tellingly, support dimensions related to curriculum development, student support, incentives for course development, and promotion, retention, and recognition were ranked below average. In addition, in her survey of faculty development programs in distance education, McQuiggan (2007) found that most programs center on "step-by-step" training processes, "dissemination of information," or the "development of specific skills" (para. 39). She offered that "while there is evidence of faculty changes, there is little reporting of reflective thought, questioning of prior beliefs and assumptions about their classroom teaching, or rethinking their teaching philosophy" (para. 2). These activities (reflecting on and improving pedagogical practice, reenvisioning one's instructional role and philosophy) move beyond training to align with the aims and transformative potential of faculty and instructional development.

Findings from Bartley's (2001) study of twenty-seven higher education institutions within Ohio also confirm the tendency of faculty development programs in distance education to stress training over development. After surveying distance learning faculty and administrators and analyzing exemplary programs, Bartley concluded that "distance teaching is not just about using technology; it is about perfecting a pedagogical art for effective learning" and requires a systematic approach to "institutional collaboration and innovation" (para. 1). Indeed, calls for collaboration across academic and administrative units are prevalent in conversations about online faculty development, as well as support for face-to-face teaching at branch campuses. The American Association of University Professors and the Canadian Association of University Teachers' 2009 
joint statement asserted, "Continued pursuit of this path [establishing branch campuses, particularly internationally] will accelerate the casualization of the academic workforce, taking its toll on the quality of instruction as well as adversely affecting faculty rights." The statement concluded that faculty involvement and collaboration to create standards for curriculum development and faculty evaluation are paramount to the ongoing vitality of higher education (Jaschik, 2009, para. 2). The Association of Public and Land-Grant Universities echoed: "Campus leaders should maintain consistent communication with all faculty and administrators regarding the role and purpose of online learning programs as they relate to academic mission and academic quality ... and use communication strategies that target and engage all faculty members" (Seaman, 2009, p. 50, emphasis added).

As numbers of courses and academic programs offered by distance education modalities continue to increase, faculty developers face new opportunities and challenges to traditional models of faculty development and distance faculty training. Academic and administrative units are compelled to augment traditional technology training-oriented programs with new approaches that draw on the potential of faculty and instructional development and that work toward the goal of integrating geographically dispersed faculty.

\section{Purpose of the Study}

Our work in faculty development at institutions with multicampus structures and large online learning programs compelled the design of a research study that would connect us with campus leaders facing similar opportunities to design pedagogically focused, inclusive faculty development programs. Moreover, with two researchers personally experiencing working from a distance, we have observed firsthand the need for faculty at a distance to connect and interact with their on-campus peers in shared faculty development endeavors. Thus, we sought to:

o Identify faculty developers from diverse institutions across the country who have developed strategies for inclusive faculty development programming

o Identify the features of effective, inclusive faculty development programming

o Obtain a more comprehensive understanding of the challenges and opportunities presented by the diversification of faculty roles and geographical locations 


\section{Participants and Method}

Recognizing the complex contextual factors that affect the priorities and outcomes of faculty development at any institution, qualitative research was emphasized, consisting primarily of individual interviews with faculty developers who agreed to participate in the study by invitation. A list of potential participant institutions was compiled based on the Carnegie Basic Classifications and the Professional and Organizational Development Network in Higher Education (Professional and Organizational Development Network in Higher Education, 2007) faculty development program types: faculty committee-run programs, programs run by a single individual, centralized programs, and decentralized programs. Given our focus on learning from institutions with established distance learning programs, we cross-referenced institutional member lists from the Sloan Consortium and the Western Cooperative of Educational Technologies. Volunteer participants were recruited through e-mail invitation and asked to complete an informed-consent form prior to the interview.

A range of institutional classifications and faculty development program types was involved in the study. The majority of the institutions (approximately 70 percent) were POD members. In total, thirty institutions were involved in the study, with interviewees providing information on institutional dynamics and faculty development initiatives for geographically dispersed faculty. Represented in the sample are the following institution types: 73.3 percent public, 20 percent private nonprofit, and 6.7 percent private for profit. Using the ATLAS.ti qualitative analysis software, we coded interview transcripts and researcher notes and identified content themes based on the frequency of terms and topics, as well as themes suggested by the interview questions (see the appendix at the end of the chapter).

\section{Results}

The topics emerging from the interview transcript analysis resulted in five overarching categories (with percentage of total responses for each category indicated):

- Guiding perceptions of faculty development needs ( 11 percent)

- Emergent trends in inclusive faculty development programming (27 percent)

o Scope of faculty development (18 percent)

o Institutional position of faculty development (32 percent)

- Integration of faculty development with academic departments (12 percent) 
For the purposes of presenting these data, we collapsed these five topics into two overarching content themes correlated to the study objectives: guiding perceptions and emerging trends, and organizational challenges.

\section{Guiding Perceptions and Emerging Trends}

Interview participants provided contextual information about their institutions, including number of full-time and adjunct faculty teaching in various modalities and the support structures in place for distance faculty. Emerging structures revealed through the interviews were consistent with trends noted in the literature: although the majority of full-time faculty at the institutions participated in some way in distance education, most notably online teaching and course development, most of the geographically dispersed faculty were adjuncts teaching online or at branch campuses. In addition to faculty demographics, two data themes surfaced that directly related to our objective of uncovering inclusive faculty development strategies:

- Theme 1: Guiding perceptions of faculty development needs

$\circ$ Theme 2: Emergent trends in inclusive faculty development programming

A significant amount of interview dialogue addressed the underlying assumptions commonly held about the needs of geographically dispersed faculty. Consistent with the literature reviewed, the guiding perceptions of geographically dispersed faculty development centered on technology training and orientation to institutional policies and procedures. These perceptions were most evident when the directors of centralized teaching centers referred us to campus distance and continuing education offices or instructional technology offices when asked to talk about their support of geographically dispersed faculty. Even when discussed in the context of centralized faculty development, geographically dispersed faculty needs were almost exclusively described in terms of technology training. For example, one participant shared: "The idea is to prepare them to teach online and they are all over the range in terms of their current skills and abilities, but ultimately we have a series of outcomes we want to get all [of] our faculty to-toward teaching online and that's what we work towards."

Another interviewee highlighted the importance of training based on the university's learning management system (LMS):

The university is encouraging people to go hybrid and to use the [LMS] system as a supplement for readings, course scheduling, and so 
forth. But what we're recognizing is that the model that we've used to do LMS training and course design, which have kind of come together in a lot of ways for the online faculty, is just not scalable when you are dealing with the whole campus.

\section{Another interviewee echoed:}

I think most faculty need to know how to use the learning management system (the basics, such as Gradebook, etc.). They also need a lot of pedagogical support when they first start, and our instructional designers work with those who are going to be teaching students through [the LMS system] and we've been asked to help all of our faculty who will be using the system.

To be sure, interview participants shared practical strategies for measuring such needs, including use of Web-based surveys and focus groups. Importantly, participants cautioned against the assumption that geographically dispersed faculty necessarily desire online training. However, it is clear that much outreach to geographically dispersed faculty comes in the form of encouragement to use the technologies their institutions have adopted. The pressure to implement mandated trainings for faculty at a distance often results in little time for conversations about how technology can directly affect and improve student learning or dialogue among diverse faculty constituents about how they have used such technologies to improve teaching and learning.

The interview data also uncovered emergent trends in faculty development and examples of innovative programming across institution types. Although a vast majority of these trends pertained to technology training, of particular note were efforts involving the use of various technologies (for example, LMS and virtual conferencing software) to deploy inclusive, dialogue, and constructivist-oriented approaches to training, specifically those that integrated technology training with pedagogical application. For example, some institutions have replaced individual online course development with a program development approach in which an instructional designer works with groups of faculty to envision and create an entire program. An interviewee described such a program:

The way we've worked with faculty in the past is through one-on-one relationships where we identify a course or program that we are going to help. What we started doing is having program development rather than individual course development ... where we would have groups of faculty coming together with one instructional designer to talk about the best approach for that program. And what we anticipate, 
what we think we found this first semester trying that, is the faculty actually serve as much as a resource as the designer and they are able to bounce ideas off one another and it saves us.... Instead of seven or eight individual conversations, presentations, and discussions we now have one that serves many folks.

This collaborative approach productively disrupts the dyad of traditional course development and allows room for faculty to collaboratively generate not only content but also programwide pedagogical strategies. Several institutions reported involving adjunct faculty who routinely teach a course online or at a branch campus to participate in course redesign and redevelopment with a full-time faculty content developer.

In addition to such task-specific collaborations, other institutions reported virtual, asynchronous teaching and learning conferences, which serve to link affiliate faculty from across the country (and even the world) with their academic departments to discuss student outcomes and curriculum consistency across instructional modalities and locations. Online special interest groups housed within an LMS are encouraged at some institutions; forming organically around instructor-identified topics of interest, these groups blur the line between on- and off-campus faculty. Some institutions are creating ways to reach their faculty through their own networked learning communities, as one study participant described:

We have a series of podcasts that will be posted to our Web site ... and the vision is for our center to be a place where faculty can come anytime they want to be able to hear about what we do so they can download presentations/podcasts to their smart phones and listen to them ... and some of their resources will be unique to the Web site where faculty can also be pointed to other resources online and to access resources directly.

Another participant added, "We've created something called 'the village' for a virtual faculty open forum and discussion area; some are general discussion areas, and some are by discipline."

Open access academic commons or community-constructed repositories of pedagogical tips also acknowledge the expertise and contributions of distributed and contingent faculty. And certificate programs, both intra- and cross-institutional, most often facilitated through LMSs, were cited as a means of professionalizing contingent faculty roles and restoring the pedagogical and professional development dimensions to adjunct faculty hiring and preparation. Thus, despite a persistent emphasis on 
technology, there is evidence that some institutions are increasingly prioritizing pedagogy over training.

\section{Organizational Challenges}

Over half of the data themes related to the organization of and resource allocation for faculty development at participants' institutions. Approaching the interviews, we assumed that discussion of organizational dynamics would be little more than a naturally occurring outcome of our research. Our principal goal was to uncover strategies and best practices for inclusive faculty development-that is, faculty development designed for and accessible to both full-time and adjunct faculty, regardless of instructional modality or geographical location. We perceived that discussions about the infrastructure of faculty development would be limited to information gathering about institutional models and demographics. However, several of the final data themes related to organizational dynamics:

- Theme 3: Scope of faculty development

- Theme 4: Institutional position of faculty development

- Theme 5: Integration of faculty development with academic departments

The scope of faculty development for distance faculty directly correlated to the institutional position of faculty development entities. We found, overwhelmingly, that geographically dispersed faculty were rarely considered a primary audience for centralized faculty development centers, even those including adjunct faculty in their mission statements. Instead and certainly tied to the guiding perceptions of distance faculty development, most faculty development professionals referred us to administrative leadership within distance and continuing education offices for more information about support for geographically dispersed faculty. This pattern proved significant: it suggested that traditional teaching and learning centers are not equipped for, or do not see as part of their responsibilities, supporting full-time and adjunct faculty who are geographically removed from the institution's flagship campus. One participant said:

The center handles the faculty development initiatives for our face-toface trainings. Academic Affairs oversees the training, hiring, and supervision of the distance faculty. Most distance faculty are adjuncts that are working from a distance. All distance faculty are required to complete a moderated three-week training course and are subject 
to ongoing peer review. Course development happens as a separate process that is done out of Curriculum Services.

Another interviewee explained:

We mostly work with faculty who are on campus. We've been sensitized, as we have an outreach school responsible for the distance learning, and they have moved more and more to the model that the faculty who teach in the outreach courses are supposed to be faculty who are hired by departments.

Varying functions and roles also exist within each faculty development center as described by this study participant: "Academic parts all belong to the academic departments; we just provide support services. We do market analysis, marketing, recruiting, course design and development, student services, advising, and financial aid." This organizational dynamic could help explain the persistent emphasis on technology training and policy orientation we uncovered.

To address this fragmentation of technologically and pedagogically oriented development initiatives, several institutions have begun to forge intentional partnerships and networks among leaders from perennially disparate campus entities (for example, department heads, faculty developers, instructional technologists, assessment experts, and administrative personnel in extended, continuing, and distance studies). These partnerships are often realized by creating new roles or collaborations-for instance, faculty who are granted instructional release time to serve as liaisons or translators of distance learning procedures and policies to their department colleagues; administrative positions, funded by the distance learning administrative office, that "live" in the academic departments; faculty development positions for branch campuses; and university committees that routinely bring together administrative leaders from distance learning, academic technologies, and faculty development centers to assess duplication of services, resources, and initiatives. These models work against a top-down or unilateral approach to emphasize an inclusive, collaborative dynamic for identifying and addressing the needs of all faculty, regardless of location.

\section{Discussion}

Our conversations with faculty developers and distance education administrative leaders about the scope, organization, institutional position, and audiences for faculty development belied larger epistemological issues related to the purposes and outcomes of such efforts. As a way of framing 
such issues, the literature on knowledge management offers language for identifying and articulating a distinction between training and development, between explicit and tacit knowledge prioritization. This research has been used to theorize a number of issues in higher education (Carlson, 2002; Kidwell, Vander Linde, \& Johnson, 2000; Serban \& Luan, 2002) and can capture the epistemological and related structural issues that emerged from our study.

Through the lens of knowledge management, we generalized that most faculty development programs operating out of traditional, centralized university teaching centers privilege tacit knowledge, understood as the combination of "information with experience" (Carlson, 2002, p. 8). Cultivation of tacit knowledge requires programs and venues that engage faculty in mentoring relationships and provide opportunities for ongoing, informal dialogue about teaching scenarios and challenges, placing the explicit knowledge of policy and procedure into a meaningful context. Such initiatives foster a sense of loyalty to the institution by conveying a regard for the professional growth of full-time and adjunct faculty and the ongoing improvement of curriculum and student learning. Inherent in this orientation toward tacit knowledge is an emphasis on creating a community of scholars and valuing each faculty member as a contributor to larger, more inclusive faculty development efforts. Conversely, faculty development programs emanating from administrative units within distance learning offices possessed more strengths in the domain of explicit knowledge. As such, focus is often placed on disseminating how-to technical knowledge and performance expectations, as opposed to fostering an integrated faculty community. In this orientation, faculty are passive recipients of explicit knowledge, with few opportunities to contribute their expertise or build their professional skills. To be sure, both tacit and explicit knowledge are essential for wellrounded professional development, which suggests a need for models that take advantage of both knowledge paradigms. As expressed in Table 1.1, hybridizing or networking centralized and decentralized resources involves grounding faculty in the explicit knowledge they need to succeed in particular institutional and disciplinary contexts, while also fostering the tacit knowledge that derives from experience and is generated in communities.

\section{Implications}

Devising inclusive faculty development initiatives starts with interrogating persistent and limiting assumptions about the needs of geographically dispersed faculty. Such assumptions include privileging the transmission of explicit knowledge, especially in the form of technological and procedural 
Table I.I Knowledge Management Analysis of Professional Development Paradigms for Geographically Dispersed Faculty.

\begin{tabular}{|c|c|c|}
\hline & Explicit Knowledge & Tacit Knowledge \\
\hline Features & $\begin{array}{l}\text { Easily codified } \\
\text { Storable } \\
\text { Transferable } \\
\text { Easy to capture and } \\
\text { share } \\
\text { Orients } \\
\text { Transmits knowledge } \\
\text { Reflects institutional } \\
\text { identity } \\
\text { Overemphasized }\end{array}$ & $\begin{array}{l}\text { Personal } \\
\text { Context specific and } \\
\text { situational } \\
\text { Difficult to formalize } \\
\text { Difficult to capture and } \\
\text { share } \\
\text { Equips } \\
\text { Facilitates community } \\
\text { Creates institutional } \\
\text { loyalty } \\
\text { Deemphasized or } \\
\text { neglected }\end{array}$ \\
\hline Sources, scope & $\begin{array}{l}\text { Scripted, formal } \\
\text { Institutional } \\
\text { perspectives } \\
\text { Current understandings } \\
\text { Administratively driven } \\
\text { University centered }\end{array}$ & $\begin{array}{l}\text { Informal, organic } \\
\text { Personal faculty } \\
\text { experiences } \\
\text { Historical } \\
\text { understandings } \\
\text { Faculty and department } \\
\text { driven } \\
\text { Discipline centered }\end{array}$ \\
\hline Venues & $\begin{array}{l}\text { Instructions } \\
\text { Policy statements } \\
\text { Training modules, } \\
\text { Webinars } \\
\text { Static Web site content } \\
\text { Newsletters } \\
\text { Tips and strategies } \\
\text { Technology help pages }\end{array}$ & $\begin{array}{l}\text { E-mentoring } \\
\text { Interactive, application- } \\
\text { oriented modules } \\
\text { Dynamic Web site } \\
\text { content } \\
\text { Discussion boards } \\
\text { Instructor blogs } \\
\text { Community wikis }\end{array}$ \\
\hline Institutional models & Centralized & Decentralized \\
\hline
\end{tabular}

Source: Adapted from Serhan and Luan $(2002, p .10)$.

support (for example, how to use an LMS; how to respond to student incivility, a grade challenge, or an instance of plagiarism), over engaging distance faculty in conversations about disciplinary content and pedagogical strategy.

Explicit knowledge in the form of technology training and instructional policies and procedures, for example, equips faculty with the resources to perform effectively and uphold institutional practice. This type of explicit knowledge is especially important to the process of 
orienting new faculty, but it should not comprise the whole of faculty development programming. Explicit knowledge in the form of best practices for pedagogy should be captured from across the faculty communities (full time, adjunct, distance, and local) and disseminated in ways that support the general and discipline-specific pedagogical effectiveness of all faculty. In addition, tacit knowledge-that which is constructed through interaction and builds community at the same time that it advances practice-must be far from a secondary concern. Faculty development initiatives must be equally concerned with capturing and disseminating explicit knowledge and fostering tacit knowledge, recognizing that, "ironically, in most of today's human systems, enormous quantities of explicit knowledge may actually hinder the emergence of tacit knowledge in individuals, as members of the organization struggle just to keep from drowning in the flood of information" (Carlson, 2002, p. 8).

A final, overarching implication of this study points to the value of leveraging collaboration to create hybrid models for faculty development. Faculty development initiatives should strive to move beyond information transfer to help faculty build communities of practice around academic disciplines and instructional modalities. While communities of practice can be administrated in a centralized manner, they are decentralized by nature. Velez (2009) summarized the foundational research on communities of practice:

Members of a Community of Practice are brought together through joint enterprise, which is a set of common activities and common goals that are understood and continually renegotiated by the members. ... MUTUAL ENGAGEMENT sustains the Community of Practice because they are bound by their common goals and become a social entity. ... [Finally,] the Community of Practice has a shared repertoire of communal resources like routines, language, styles, habits, that the group members develop over a period of time [para. 3].

Faculty development professionals can take their cues from the community of practice approach by seeking to collaborate across institutional divisions (academic and administrative) and organizing opportunities around common problems and authentic contexts.

\section{Conclusion}

Our study suggests there is much value in creating structures and programs that incorporate flexibility for both integration and differentiation of faculty communities, academic disciplines, and administrative 
units-dependent on the audience, topic, and learning objective of the training or development. The study points to a need for initiatives that more substantially support the pedagogical effectiveness of geographically dispersed faculty, full-time and adjunct, as well as that help faculty build communities of practice around academic disciplines and instructional modalities. While technology training and practical orientation are necessary, the cultivation and dissemination of tacit knowledge, that is, lived wisdom, draw on the potential of professional and instructional development integrating faculty with diverse appointments and locations.

\section{Appendix: Interview Questions}

- What are the mission and goals of your faculty development center? How do these relate to your institution's mission, goals, and culture?

- Whom does your center serve? Is the center a centralized academic resource, serving all disciplines and instructional modalities?

- Does the scope of your faculty development programming extend to faculty working at a distance? Both those teaching online and face-to-face?

- How is distance education coordinated at your institution? To what extent is it centralized through the academic departments? How does the organization of distance education affect faculty development services?

o What specific professional development needs do you perceive (or perhaps that you have learned from assessment) relevant to faculty working from a distance? How do these compare to the needs of other faculty?

- What are some of the challenges that you've encountered in supporting the work of faculty working from a distance?

- Are these challenges similar or different across full-time and adjunct faculty populations?

o What faculty development resources do you offer to faculty working from a distance? Do you attempt to make all flagship/central/ main campus resources available to those off-campus, or is the programming distinct?

- Which of your faculty development resources/programs/initiatives has been most used by faculty working from a distance? 
o Based on your experiences, which faculty development programming features work best for faculty working from a distance, and which do not?

\section{REFERENCES}

Allen, I. E., \& Seaman, J. (2010). Class differences: Online education in the United States. Sloan Consortium. Retrieved from http://sloanconsortium. $\mathrm{org} /$ sites/default/files/class_differences.pdf

Bartley, J. M. (2001). Faculty training and development initiatives for effective instruction in distance education. Cincinnati, $\mathrm{OH}$ : University of Cincinnati Press.

Bower, B. (2001). Distance education: Facing the faculty challenge. Online Journal of Distance Learning Administration, 2(1). Retrieved from http:/l www.westga.edu/ distance/ojdla/summer42/bower 42 .html

Carlson, P. (2002). A community of practice: Web portals and faculty development. Journal of Computing in Higher Education, 13(2), 4-24.

Cranton, P. (2005). Not making or shaping: Finding authenticity in faculty development. In S. Chadwick-Blossey \& D. R. Robertson (Eds.), To improve the academy: Resources for faculty, instructional, and organizational development, Vol. 24 (pp. 70-85). San Francisco, CA: Jossey-Bass/ Anker.

Eaton, J. (2001). Distance learning: Academic and political challenges for bigher education accreditation. Retrieved from http://www.chea.org/pdf/ mono_1_dist_learning_2001.pdf

Gappa, J. M., Austin, A. E., \& Trice, A. C. (2007). Rethinking faculty work: Higher education's strategic imperative. San Francisco, CA: Jossey-Bass.

Jaschik, S. (2009). Scrutiny and standards for branch campuses. Inside HigherEd. Retrieved from http://www.insidehighered.com/ news/2009/04/09/branch

Kidwell, J., Vander Linde, K., \& Johnson, S. (2000). Applying corporate knowledge management practices in higher education. EDUCAUSE Quarterly, 23(4), 28-33.

McQuiggan, C. A. (2007). The role of faculty development in online teaching's potential to question teaching beliefs and assumptions. Online Journal of Distance Learning Administration, 10(3). Retrieved from http://www. westga.edu/ distance/ojdla/summer 122/velez122.html

National Center for Education Statistics. (2010). Digest of education statistics, 2010: Table 25.5. Retrieved from http://nces.ed.gov/programs/digest/d10/ tables/dt10_255.asp?referrervreport 
Professional and Organizational Development Network in Higher Education.

(2007). What is faculty development? Retrieved from http://www.podnetwork.org/faculty_development/definitions.htm

Seaman, J. (2009). The paradox of faculty voices: Views and experiences with online learning. Washington, DC: Association of Public and Land-Grant Universities. Retrieved from http://sloanconsortium.org/sites/default/files/ APLU_online_strategic_asset_vol2-1.pdf

Serban, A. M., \& Luan, J. (2002). Overview of knowledge management. In A. M. Serban \& J. Luan (Eds.), New directions for institutional research, No. 11.3. Knowledge management: Building a competitive advantage in higher education (pp. 5-16). San Francisco, CA: Jossey-Bass.

Velez, A. (2009). The ties that bind: How faculty learning communities connect online adjuncts to their virtual institutions. Online Journal of Distance Learning Administration, 12(2). Retrieved from http://www.westga .edu/ distance/ojdla/summer122/velez122.html 